\title{
NURSING PROFESSIONALISM IN OCCUPATIONAL HEALTH AND SAFETY RISK MANAGEMENT AT PKU MUHAMMADIYAH HOSPITAL, KARANGANYAR, CENTRAL JAVA
}

\author{
Dewi Arradini'1,2), Dewi Wulandari²) \\ 1)Masters Program in Business Law, Universitas Gadjah Mada, Yogyakarta \\ 2)Study Program of Nursing, School of Health Sciences Mitra Husada, Karanganyar
}

\begin{abstract}
Background: Law number $38 / 2014$ on nursing requires nurses to provide professional services. Unprofessional nurse increases health and safety risk of themselves. This study aimed to describe nursing professionalism in occupational health and safety risk management at PKU Muhammadiyah Hospital, Karanganyar, Central Java.

Methods: This was a qualitative study conducted at PKU Muhammadiyah Hospital in Karanganyar, Central Java, from December 2018 to February 2019. The main study focus was nursing professionalism in occupational health and safety risk management. The data were obtained by in-depth interview and analyzed by content analysis, including data reduction, presentation, and conclusion.

Results: Nurses' ages ranged from 18 to 35 years. Nursing professionalism in occupational health and safety risk management at PKU Muhammadiyah Hospital was good. In order to maintain and improve nursing professionalism, internal hospital training and regular coordination meeting were conducted, involving ward nurses and heads, and nursing committee. Occupational health and safety risks were minimal. Near-miss and accident cases were recorded and followed up for future preventive purpose.

Conclusion: Nursing professionalism in occupational health and safety risk management at PKU Muhammadiyah Hospital is good. Some preventive measures had been taken to minimize occupational health and safety risk.
\end{abstract}

Keywords: nursing, professionalism, risk management

\section{Correspondence:}

Dewi Arradini. Masters Program in Business Law, Universitas Gadjah Mada, Yogyakarta/ Study Program of Nursing, School of Health Sciences Mitra Husada, Karanganyar, Jl. Achmad Yani No 167, Papahan, Tasikmadu, Karanganyar, Surakarta, Central Java. Email: dewiarra29@gmail.com. Mobile: 08994194149.

The $6^{\text {th }}$ International Conference on Public Health Best Western Premier Hotel, Solo, Indonesia, October 23-24, 2019 | 241 https://doi.org/10.26911/the6thicph.04.03 